OPEN ACCESS

Edited by:

Julio Cesar Rosa-e-Silva, University of São Paulo, Brazil

Reviewed by:

Takayuki Ueno,

Kyorin University, Japan

Alfredo Ribeiro-Silva,

University of São Paulo, Brazil

*Correspondence:

Tania L. Slatter

tania.slatter@otago.ac.nz

Specialty section: This article was submitted to Women's Cancer,

a section of the journal

Frontiers in Oncology

Received: 29 October 2015 Accepted: 21 December 2015 Published: 21 January 2016

Citation:

Royds JA, Pilbrow AP, Ahn A, Morrin HR, Frampton C, Russell IA, Moravec CS, Sweet WE, Tang WHW, Currie MJ, Hung NA and Slatter TL (2016) The rs 11515 Polymorphism Is More Frequent and Associated With

Aggressive Breast Tumors with Increased ANRIL and Decreased p16 ${ }^{\text {INK4a }}$ Expression. Front. Oncol. 5:306. doi: 10.3389/fonc.2015.00306

\section{The rs11515 Polymorphism Is More Frequent and Associated With Aggressive Breast Tumors with Increased ANRIL and Decreased p16 ${ }^{\text {INK4a }}$ Expression}

Janice A. Royds' ${ }^{1}$ Anna P. Pilbrow ${ }^{2}$, Antonio Ahn ${ }^{1}$, Helen R. Morrin ${ }^{3}$, Chris Frampton ${ }^{2}$, I. Alasdair Russell ${ }^{4}$, Christine S. Moravec ${ }^{5}$, Wendy E. Sweet ${ }^{5}$, W. H. Wilson Tang ${ }^{5}$, Margaret J. Currie ${ }^{3}$, Noelyn A. Hung ${ }^{1}$ and Tania L. Slatter ${ }^{*}$ *

\footnotetext{
${ }^{1}$ Department of Pathology, Dunedin School of Medicine, University of Otago, Dunedin, New Zealand, ${ }^{2}$ Department of Medicine, University of Otago, Christchurch, New Zealand, ${ }^{3}$ Department of Pathology, University of Otago, Christchurch, New Zealand, ${ }^{4}$ Cancer Research UK Cambridge Institute, University of Cambridge, Cambridge, UK, ${ }^{5}$ Department of Cardiovascular Medicine, Kaufman Center for Heart Failure, Cleveland Clinic, Cleveland, OH, USA
}

Chromosome position 9p21 encodes three-tumor suppressors p16 ${ }^{\text {INK4a }}$, p14 ${ }^{\text {ARF }}$, and p15 INK4b and the long non-coding RNA ANRIL (antisense non-coding RNA in the INK4 locus). The rs 11515 single-nucleotide polymorphism in the $p 16^{\text {INK } 4 a / p 14^{A R F}} 3^{\prime}$-untranslated region is associated with glioblastoma, melanoma, and other cancers. This study investigated the frequency and effect of rs11515 genotypes in breast cancer. Genomic DNA samples from 400 women (200 with and 200 without a diagnosis of breast cancer) were genotyped for the rs 11515 major $(C)$ and minor (G) alleles. The rs 11515 polymorphism was also investigated in 108 heart tissues to test for tissue-specific effects. Four 9p21 transcripts, $p 16^{I N K 4 a}, p 14^{A R F}, p 15^{I N K 4 b}$, and ANRIL were measured in breast tumors and myocardium using quantitative PCR. Heterozygotes (CG genotype) were more frequent in women with breast cancer compared to the control population $(P=0.0039)$. In those with breast cancer, the CG genotype was associated with an older age $(P=0.016)$ and increased lymph node involvement $(P=0.007)$ compared to homozygotes for the major allele (CC genotype). In breast tumors, the CG genotype had higher ANRIL $(P=0.031)$ and lower $p 16^{\text {INK4a }}(P=0.006)$ expression compared to the CC genotype. The CG genotype was not associated with altered 9p21 transcripts in heart tissue. In breast cancer, the rs 11515 CG genotype is more frequent and associated with a more aggressive tumor that could be due to increased ANRIL and reduced $p 16^{I N K 4 a}$ expression. The absence of association between rs11515 genotypes and 9p21 transcripts in heart tissue suggests this polymorphism has tissue- or disease-specific functions.

Keywords: breast cancer, ANRIL, p16 ${ }^{\text {INK4a }}$, 9p21, single-nucleotide polymorphisms, rs11515 


\section{INTRODUCTION}

Single-nucleotide polymorphisms (SNPs) within the 9p21 locus are associated with coronary artery disease (1-3) and multiple cancer types (4-7), suggesting this region is significant toward disease susceptibility. Three proteins encoded at 9p21 are welldefined tumor suppressors. The $\mathrm{p} 16^{\mathrm{INK} 4 \mathrm{a}}$ and $\mathrm{p} 15^{\mathrm{INK} 4 \mathrm{~b}}$ proteins limit cell proliferation by inhibiting cyclin-dependent kinases, and the third tumor suppressor (p14 ${ }^{\mathrm{ARF}}$ ) prevents the degradation of $\mathrm{p} 53$ [reviewed in Ref. $(8,9)]$. Different open-reading frames of the cyclin dependent kinase $2 \mathrm{~A}(C D K N 2 A)$ gene encode $\mathrm{p} 16^{\text {INK4a }}$ and p14 $4^{\mathrm{ARF}}$, while $\mathrm{p} 15^{\mathrm{INK} 4 \mathrm{~b}}$ is encoded by a separate gene $(C D K N 2 B)$.

The rs11515 polymorphism in the CDKN2A 3'-untranslated region (UTR) consists of a major $(\mathrm{C})$ and minor $(\mathrm{G})$ allele at cDNA nucleotide 500 (numbered from the $p 16^{I N K 4 a}$ initiation codon). It has been associated with melanoma, sporadic colorectal, skin, bladder, and cervical cancers (10-17). In glioblastoma, the rs $11515 \mathrm{G}$ allele was associated with a worse prognosis and older age (17). This polymorphism is $5^{\prime}$ to the long non-coding RNA ANRIL (antisense non-coding RNA in the INK4 locus, also known as CDKN2B-AS1) (18). Increased ANRIL is associated with increased proliferation, metabolic activity, inflammation, and attenuation of apoptosis (19-22). Silencing of ANRIL prevented fibroblast and smooth muscle cell proliferation $(19,20)$ as ANRIL is increased as part of a bacterial response ANRIL may function as part of an inflammatory response (22). This and other evidence, including the findings of increased ANRIL in prostate cancer, leukemia, glioma, and breast cancer suggest ANRIL, may promote tumorigenesis $(19,23-26)$.

Given the association of the CDKN2A rs11515 and the functions of proteins encoded at $9 \mathrm{p} 21$ in cancer, the current study investigated rs11515 genotypes in breast cancer.

\section{MATERIALS AND METHODS}

\section{Patients}

For the breast cancer analyses, the patient cohort consisted of 200 women diagnosed with primary breast cancer who underwent surgery at Christchurch hospital, New Zealand. The mean age for the breast cancer cohort was 59.7 years (95\% CI 57.6-61.8). Ethnicity data were available for 152 women $(87 \%$ identified as European, 3\% Maori, 3\% Maori and European, and 7\% identified with other ethnic groups). The control cohort consisted of 200 healthy women from the New Zealand population. The mean age of the control cohort was 56 years ( 95 CI percentile $54-58.5$ years). Ethnicity data were available for all in the control cohort. Eightyfive percent identified as European, 3\% Maori, 5\% Maori and European, and 7\% identified with other ethnic groups. There was no significant difference in age between the patient and control cohorts. Frozen breast tumors were available for 25 women (12 women with the CG and 13 with the CC genotype). Tumor tissue was limited for four individuals with the CG genotype; therefore, some analyses were performed on 8 instead of 12 tumors. The breast tumors were selected so that four variables were matched between those with the CG and CC genotypes (tumor grade, presence of lymph/vascular invasion, $\geq 2$ lymph nodes affected, and an estrogen-receptor positive tumor). All breast tumors were from women who did not have previous treatment with radiotherapy or chemotherapy before surgery.

For the analysis of heart tissue, tissue from the left ventricular free wall of the myocardium of organ donors $(n=108)$ was collected by the Cleveland Clinic Kaufman Center for the Heart Failure Human Heart Tissue Bank between 1993 and 2006, as previously described (27).

For the breast tumor study, ethical approval was obtained in New Zealand, and all women gave written informed consent for inclusion in the study (Ethics Committee Approvals 02.06.98/5.11.09 and LRS/10/09/035). Standard procedures were followed, which included culturally appropriate tissue handling and disposal protocols (28). For the heart tissue study, ethical approval was obtained from the Cleveland Clinic Internal Review Board (IRB 2378), and the study adhered to the principles outlined in the Declaration of Helsinki. All procedures followed were in accordance with institutional guidelines and all families and/or patients provided informed consent.

\section{Rs11515 Genotyping}

The $C$ and G rs11515 alleles were genotyped in the breast tumor and control cohorts using a PCR and restriction enzyme digestion method. Genomic DNA was extracted from blood leukocytes using the Dneasy Blood \& Tissue Kit (Qiagen, Veno, Netherlands) according to the manufacturer's instructions. A 319 bp region was amplified using the following primers: forward, 5'-TGCCACACATCTTTGACCTC-3'; reverse, 5'-GCAGAAGCGGTGTTTTTCTT-3'. Following conformation of the correct PCR product, amplified DNA was digested with the MspI restriction enzyme. Restriction enzyme-digested PCR products were separated by agarose gel electrophoresis to identify the rs11515 genotype (C allele, digested band; and G allele, undigested band). DNA sequencing was performed on 20 PCR products to confirm genotypes as described previously (17).

The C500 and G500 rs11515 alleles were genotyped in heart tissue using a Taqman SNP assay (C_12096259_10, Applied Biosystems, Foster City, CA, USA). Genomic DNA was extracted from frozen tissue as previously described (27) and from samples genotyped in duplicate using the Lightcycler 480 platform and Lightcycler 480 software, version 1.5.0 (Roche, Indianapolis, IN, USA). Reactions were optimized for $5 \mu \mathrm{L}$ volumes with $0.5 \times$ the recommended probe concentration.

\section{Rs3088440 Genotyping}

For the breast tumor study, rs3088440 alleles were genotyped in the patient and control cohorts using a PCR and restriction enzyme digestion method. A $180 \mathrm{bp}$ region was amplified from blood leukocyte genomic DNA using the following primers: forward, 5'-TAGATCATCAGTCACCGAAGG-3'; reverse, 5'-CATTTACGGTAGTGGGGGAAG-3'. Following conformation of the correct PCR product, amplified DNA was digested with the HaeIII restriction enzyme. Restriction enzyme-digested PCR products were separated by agarose gel electrophoresis to identify the major allele (digested band) and the minor allele (undigested band). DNA sequencing was performed on 20 PCR products to confirm genotypes as described previously (17). 


\section{CDKN2A Gene Dosage}

The gene dosage of $C D K N 2 A$, exon $1 \alpha\left(p 16^{I N K 4 a}\right)$, and exon $1 \beta$ $\left(p 14^{A R F}\right)$ was estimated in 13 breast tumors with the CC and 12 tumors with the CG rs11515 genotype using a multiplex PCR assay, as previously described (29). Tumor DNA was extracted using the Qiagen Dneasy Blood \& Tissue Kit according to the manufacturer's instructions (Qiagen, Limburg, The Netherlands). The intensity of the CDKN2A and $\beta$-globin PCR products was compared using Bio-Rad Quantity One software (Bio-Rad Laboratories, CA, USA) and Syngene GeneTools image software (Syngene, Cambridge, UK) as previously described (17).

\section{Quantitative Real-Time PCR}

For the breast tumor study, quantitative real-time PCR (RT-qPCR) was performed for $C D K N 2 A / p 16^{I N K 4 a}, C D K N 2 A / p 14^{A R F}$, $C D K N 2 B$, and ANRIL. RNA was extracted from frozen tissue using the Ambion Purelink RNA Mini Kit (Life Technologies, Carlsbad, CA, USA) and tissue was homogenized (gentleMACS dissociator gentleMACs, Miltenyi Biotec, GmbH, Germany) according to the manufacturers' instructions. Quantitative RT-qPCR was performed using Taqman Gene Expression assays with inventoried probes (Applied Biosystems, ThermoFisher Scientific, Waltham, MA, USA) for CDKN2A/p16 $6^{I N K 4 a}$ (assay id: Hs02902543_mH), CDKN2A/p14 ${ }^{A R F}$ (assay id: Hs99999189_m1), CDKN2B (assay id: Hs00793225_m1) and ANRIL (assay id: Hs01390879_m1). Reactions were performed in duplicate on a Lightcycler 480 platform (Roche, Basel, Switzerland) and analyzed with Lightcycler 480 software, version 1.5.0 (Roche, Basel, Switzerland). Expression levels were converted to relative quantities and normalized to tumor protein, translationally controlled 1 (TPT1, assay id Hs02621289_g1) and eukaryotic elongation factor 1A1 (EEF1A1, assay id Hs00265885_g1), two reference genes previously validated for normalization of RT-qPCR data in breast and cancer cell types $(30,31)$.

For the study of heart donors, expression data for CDKN2A/ $p 16^{I N K 4 a}$ and CDKN2A/p $14^{A R F}$ was obtained in the current study, and that for CDKN2B and ANRIL generated as part of a previous study (27) and included in the current analysis. RT-qPCR was performed using Taqman Gene Expression assays for CDKN2A/ p16 $6^{I N K 4 a}$ (assay id: Hs02902543_mH), CDKN2A/p14 $4^{A R F}$ (assay id: Hs99999189_m1), CDKN2B (assay id: Hs00793225_m1), and ANRIL (assay id: Hs01390879_m1) as described above. Expression levels were normalized to TPT1 (assay id Hs02621289_g1), EEF1A1 (assay id Hs00265885_g1) and signal recognition particle $14 \mathrm{kDa}$ (SRP14, assay id Hs03055045_g1), three reference genes previously validated for use in human myocardium (32).

\section{Statistical Analyses}

The genotype frequencies were compared between cases and controls using the Chi-square test and SHEsis software (33). For breast tumors and heart samples, clinicopathologic measures were compared between genotypes using Chi-square and one-way ANOVA followed by pairwise comparisons tests. All gene expression levels displayed skewed distributions and were $\log _{\mathrm{e}}$-transformed prior to analysis. Associations between gene expression and rs11515 genotypes were performed with analysis of variance (genotypic model), with adjustment for age, as appropriate. Correlations in expression levels between genes were tested with Pearson correlation. Statistical analyses were performed with SPSS version 22 software and $P<0.05$ was taken as a significant difference.

\section{RESULTS}

\section{The rs11515 Minor Allele Was More Frequent in Women with Breast Cancer}

The rs11515 alleles were genotyped in woman with breast cancer and healthy women. In women with breast cancer, $61 \%(n=121)$ were homozygote for the major allele (CC, genotype), $38 \%(n=76)$ were heterozygote (CG, genotype), and $1.5 \%(n=3)$ were homozygote for the minor allele (GG, genotype). The genotypes of 20 samples were confirmed using DNA sequencing ( 7 typed as CC, 10 typed as CG, and 3 typed as GG). In the control population, $76 \%(n=152)$ had the CC, $23 \%$ had the CG $(n=46)$, and $1 \%$ of women had the GG genotype. The genotype frequencies in controls were in Hardy-Weinberg equilibrium $(P=0.47)$. The CG genotype was more frequent in women with breast cancer compared to the control population $(P=0.0039)$.

Clinicopathologic variables (patient age at presentation, tumor size, the number of nodes involved, venous and lymphatic invasion, estrogen receptor, progesterone receptor, and human epidermal growth factor 2 receptor statuses) among rs 11515 genotypes are shown in Table $\mathbf{1}$ and were compared between genotypes in the breast cancer cohort. The mean age for those with the CG allele was higher (63.3 years, 95\% CI 60-66.5 years) compared to those with the CC genotype (58.2 years, $95 \% \mathrm{CI}$, 55.6-60.7 years, $P=0.016$ ). Few women had the GG genotype, but all three women with this genotype were young (aged 23, 33, and 35 years).

The CG genotype was associated with a more aggressive tumor with greater lymph node involvement. Forty-five percent of women with the CG genotype had two or more nodes with malignant cells, and $38 \%$ had no nodal involvement. In those with the CC genotype, $21 \%$ had two or more nodes with malignant cells and $60 \%$ had no nodal involvement $(P=0.007)$. The tumor size and hormone receptor statuses did not differ between the rs11515 genotypes.

The rs 11515 polymorphism is located in close proximity to another polymorphism associated with breast cancer ( $r 33088440)$ (34). To determine if rs3088440 genotypes were increased in the breast cancer cohort, the rs3088440 polymorphism was genotyped. In the breast cancer, cohort $78 \%(n=155)$ were homozygote for the major allele, $21 \%$ were heterozygote $(n=42)$, and $1.5 \%(n=3)$ were homozygote for the minor allele. In the control cohort, $82 \%(n=164)$ were homozygote for the major allele, $17 \%$ were heterozygote $(n=34)$, and $1 \%(n=2)$ were homozygote for the minor allele. The rs3088440 genotype was not significantly different in women with breast cancer compared to the control population. Nine individuals were heterozygote for both the rs11515 and rs3088440 SNPs. 
TABLE 1 | Characteristics of the 200 women with breast cancer relative to their rs 11515 genotype.

\begin{tabular}{|c|c|c|c|c|}
\hline Characteristic & \multicolumn{3}{|c|}{ rs11515 genotype } & Significance \\
\hline Age at surgery years & $58.2(55.6-60.7)$ & $63.3(60-66.5)$ & $30.3(14.1-46.5)$ & 0.0001 \\
\hline \multicolumn{5}{|l|}{ Tumor grade } \\
\hline 1 & 17 (15.2\%) & $9(11.8 \%)$ & $3(100 \%)$ & ns \\
\hline 2 & 42 (37.5\%) & 34 (44.7\%) & & \\
\hline Lymph/vascular invasion present & $37(30.6 \%)$ & 38 (50\%) & $1(33.3 \%)$ & ns \\
\hline Tumor size (mm) & $24.2(21-27.3)$ & $26.4(22.5-30.4)$ & $38.3(18.8-57.9)$ & ns \\
\hline \multicolumn{5}{|l|}{ Metastases to lymph nodes } \\
\hline None & $73(60.3 \%)$ & $29(38.2 \%)$ & $1(33.3 \%)$ & 0.007 \\
\hline 1 node & $23(19 \%)$ & $13(17.1 \%)$ & $1(33.3 \%)$ & \\
\hline$\geq 2$ nodes & $25(20.7 \%)$ & $34(44.7 \%)$ & 1 (33.3\%) & \\
\hline Equivocal & $6(5.4 \%)$ & $4(5.3 \%)$ & & \\
\hline Data not known & 10 & 0 & & \\
\hline \multicolumn{5}{|l|}{ Progesterone receptor } \\
\hline Negative & $47(42 \%)$ & $31(40.8 \%)$ & $1(33.3 \%)$ & ns \\
\hline Positive & $56(50 \%)$ & $37(48.7 \%)$ & $2(66.7 \%)$ & \\
\hline Equivocal & $9(8 \%)$ & $8(10.5 \%)$ & & \\
\hline Data not known & 9 & 0 & & \\
\hline \multicolumn{5}{|l|}{ HER2 receptor } \\
\hline Negative & 30 (58.8\%) & $24(75 \%)$ & $2(66.7 \%)$ & ns \\
\hline Positive & $16(31.4 \%)$ & $8(25 \%)$ & $1(33.3 \%)$ & \\
\hline Equivocal & $5(9.8 \%)$ & 0 & & \\
\hline Data not known & 69 & 44 & & \\
\hline
\end{tabular}

Results are the mean (95\% confidence intervals), or the $n$ value (percent positive).

$P$ values represent the comparison between three genotypes.

ns, not significant.

\section{The CG Genotype Was Associated With Increased ANRIL Expression in Breast Tumors}

In glioblastoma patients, the CG genotype was associated with increased loss of $p 16^{I N K 4 a}$ and $p 14^{A R F}$ due to gene deletions at $9 \mathrm{p} 21$ (17). To determine if this was the case in breast cancer, DNA was isolated from 25 breast tumors (12 from women with the CG genotype and 13 with the CC genotype), and multiplex PCR used to estimate the gene dosage of CDKN2A exon 1a $\left(p 16^{I N K 4 a}\right)$ and exon $1 \mathrm{~b}\left(p 14^{A R F}\right)$ relative to an internal beta-globin gene fragment (29). All breast tumors had retained exon $1 \mathrm{a}$ and exon $1 \mathrm{~b}$ (data not shown), suggesting the CG genotype was not associated with loss of $p 16^{I N K 4 a}$ and $p 14^{A R F}$ gene dosage.

Polymorphisms in CDKN2A/2B/ANRIL may regulate gene expression within the cluster. To test this hypothesis, we investigated associations between rs11515 genotypes and expression of CDKN2A (transcripts, $p 16^{I N K 4 a}$ and $p 14^{A R F}$ ), and CDKN2B in 25 breast tumors ( 12 from women with the CG genotype and 13 with the CC genotype). Due to the limited availability of tumor tissue for those with the CG genotype, ANRIL was measured in 21 breast tumors ( 8 from women with the CG genotype and 13 with the CC genotype).
Compared to the CC genotype, the CG genotype was associated with lower expression of $C D K N 2 A / p 16^{I N K 4 a}$ [2.6-fold, $P=0.006$ (adjusted for age), Figure 1A] and higher expression of ANRIL (2.3-fold, $P=0.031$, Figure 1B). There was no difference in expression of $C D K N 2 A / p 14^{A R F}(P=0.513$, Figure $1 C)$ or $C D K N 2 B[P=0.404$ (adjusted for age), Figure 1D] between the genotype groups.

Because ANRIL may regulate the expression of CDKN2A/ $p 16^{I N K 4 a}$ and because expression levels of both of these genes were altered in association with the rs 11515 genotype, we investigated the relationship between rs 11515 genotype, ANRIL, and CDKN2A/p $16^{I N K 4 a}$ expression further, using analysis of covariance. We identified a significant interaction between rs11515 and ANRIL on expression of CDKN2A/p16 $6^{I N K 4 a}$ : in patients with a CG genotype levels of $A N R I L$ were strongly negatively correlated with levels of $C D K N 2 A / p 16^{I N K 4 a}$ (Pearson Correlation Coefficient $=-0.941, P<0.001$, Figure 2A), whereas in CC patients there was no correlation between ANRIL and CDKN2A/p16 $6^{\text {INK4a }}$ (Pearson Correlation Coefficient $=0.079$, $P=0.798$, Figure 2B). The interaction between rs11515 and ANRIL on CDKN2A/p16 ${ }^{I N K 4 a}$ expression remained significant after adjustment for age (adjusted $P=0.014$ ) indicating that the relationship between rs11515, ANRIL, 

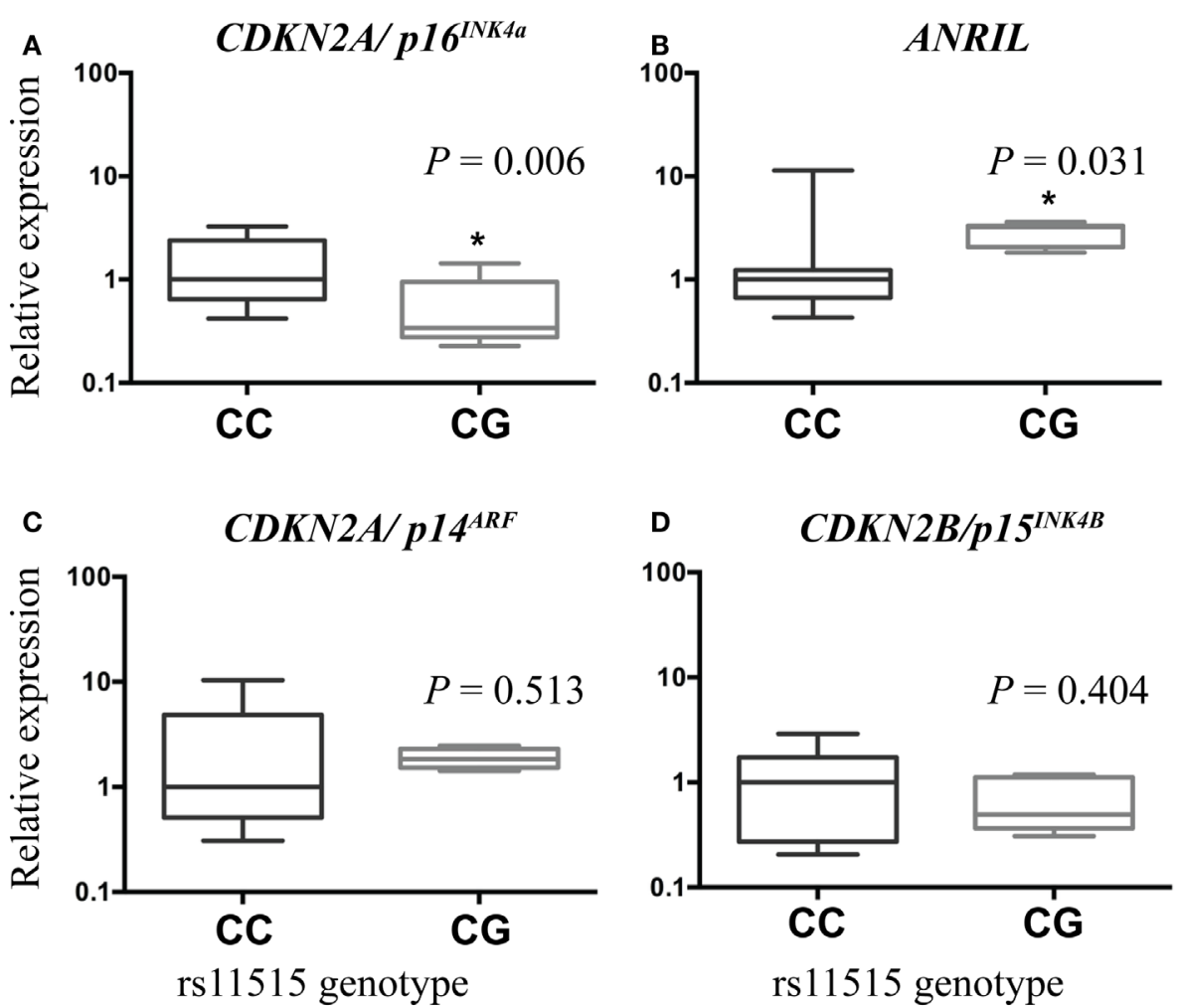

FIGURE 1 | Boxplots illustrating associations between gene expression and rs11515 genotypes in breast tumor samples. Compared with tumors with a CC genotype, expression of CDKN2A/p16 INK4a was lower (A) and expression of ANRIL was higher (B) in tumors with a CG genotype. There were no associations between rs11515 genotype and expression levels of CDKN2A/p14 ARF (C) or CDKN2B/p15 ${ }^{\text {INK4b }}$ (D) between CG and CC genotypes in breast tumor tissue.
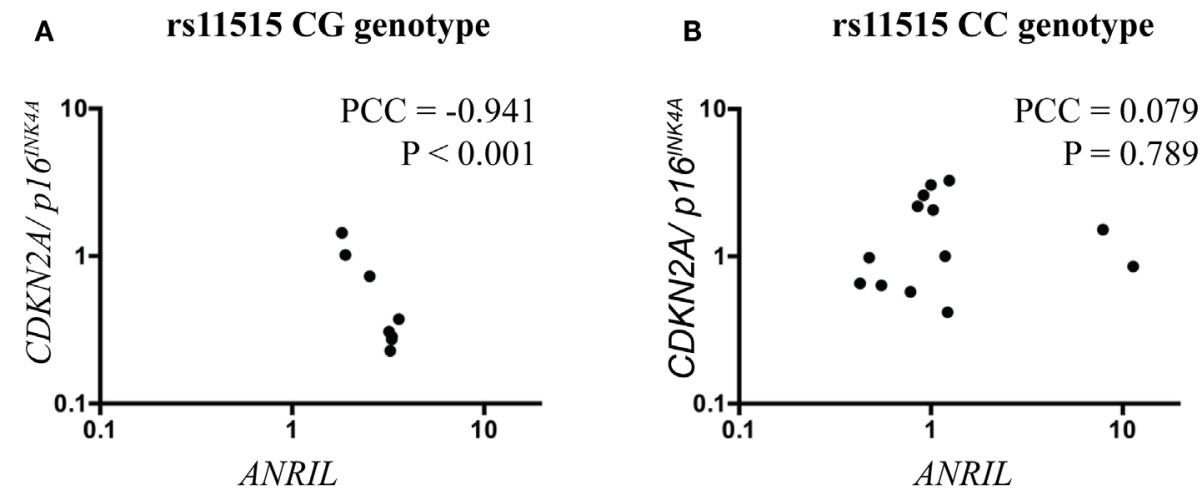

FIGURE 2 | Scatterplots illustrating the interaction between rs11515 genotypes and ANRIL on CDKN2A/p16 ${ }^{\text {INK4a }}$ gene expression in breast tumor samples. (A) In tumors with a CG genotype, ANRIL and CDKN2A/p16 INK4a levels were strongly negatively correlated. (B) In contrast, in tumors with a CC genotype, ANRIL and CDKN2ANP16 $6^{\text {NK4a }}$ levels were not correlated. PCC = Pearson correlation coefficient.

and $C D K N 2 A / p 16^{I N K 4 a}$ was not influenced by this potential confounding factor.

To test whether the association between rs11515 genotypes and altered expression of the CDKN2A/2B/ANRIL cluster occurred in other tissues, we investigated rs11515 genotypes in 108 heart donors. The rs11515 genotype frequencies in heart donors were CC $67.6 \%(n=73)$, CG $28.7 \%(n=31)$, and GG $3.7 \%(n=4)$ and were in Hardy-Weinberg equilibrium $(P=0.755)$. There were no associations between rs11515 genotypes and age and left ventricular ejection fraction and cause of death (Table 2). There were also no associations between rs11515 genotype and expression of CDKN2A/p16 $6^{I N K 4 a}(P=0.940), C D K N 2 A / p 14^{A R F}$ $(P=0.641), C D K N 2 B(P=0.116)$, or ANRIL $(P=0.701)$ in myocardium. No interaction between the rs11515 genotype and 
ANRIL on CDKN2A/p16 ${ }^{I N K 4 a}$ levels $(P=0.124)$ was identified. In heart donors, there was no significant interaction between rs11515 genotypes and ANRIL on expression of CDKN2A/p $16^{I N K a}$, Figure 3. All myocardial gene expression analyses were adjusted for age and gender. These results suggest the effect of rs11515 genotypes on 9p21 gene expression is tissue and or disease related.

\section{DISCUSSION}

The current study adds breast cancer to a growing list of malignancies associated with the rs11515 minor allele (10-17). The CG genotype was more frequent in those with breast cancer, associated with an older age and a more invasive tumor, and found with a negative correlation between ANRIL and $p 16^{I N K 4 a}$. These data suggest the CG genotype is associated with a more aggressive tumor.

Reduced $\mathrm{p} 16^{\mathrm{INK4a}}$ tumor suppressor function in combination with increased ANRIL offers an explanation for increased

TABLE 2 | Characteristics of the 108 heart donors relative to their rs11515 genotype.

\begin{tabular}{|c|c|c|c|c|}
\hline \multirow[t]{2}{*}{ Characteristic } & \multicolumn{3}{|c|}{ rs11515 genotype } & \multirow[t]{2}{*}{ Significance } \\
\hline & $\begin{array}{c}\text { CC } \\
(n=73)\end{array}$ & $\begin{array}{c}\text { CG } \\
(n=31)\end{array}$ & $\begin{array}{c}\text { GG } \\
(n=4)\end{array}$ & \\
\hline Age (years) & $\begin{array}{c}47.9 \\
(45.0-50.9)\end{array}$ & $\begin{array}{c}46.5 \\
(41.9-51.0)\end{array}$ & $\begin{array}{c}57.0 \\
(44.5-69.5)\end{array}$ & 0.294 \\
\hline \multicolumn{5}{|l|}{ Gender } \\
\hline Male & $41(56.2 \%)$ & 12 (40.0\%) & $2(50.0 \%)$ & 0.328 \\
\hline Female & $32(43.8 \%)$ & $18(60.0 \%)$ & 2 (50.0\%) & \\
\hline $\begin{array}{l}\text { Left ventricular } \\
\text { ejection fraction (\%) } \\
\text { Cause of death }\end{array}$ & $\begin{array}{c}53.0 \\
(48.1-57.9)\end{array}$ & $\begin{array}{c}49.4 \\
(41.6-57.2)\end{array}$ & $\begin{array}{c}54.2 \\
(36.1-72.2)\end{array}$ & 0.722 \\
\hline $\begin{array}{l}\text { Cerebral vascular } \\
\text { accident }\end{array}$ & $52(71.2 \%)$ & $22(73.3 \%)$ & $4(100.0 \%)$ & 0.986 \\
\hline Gun shot wound & $7(9.6 \%)$ & $3(10.0 \%)$ & $0(0.0 \%)$ & \\
\hline Motor vehicle accident & $7(9.6 \%)$ & $2(6.7 \%)$ & $0(0.0 \%)$ & \\
\hline Head trauma & $5(6.8 \%)$ & $2(6.7 \%)$ & $0(0.0 \%)$ & \\
\hline Anoxia & $2(2.7 \%)$ & $1(3.3 \%)$ & $0(0.0 \%)$ & \\
\hline
\end{tabular}

Results are the mean (95\% confidence intervals) or the $n$ value (percent positive).

$P$ values represent the comparison between three genotypes. cancer susceptibility with the rs11515 minor allele. An association between the CG genotype and lower expression of $p 16^{I N K 4 a}$ is consistent with previous studies. In melanoma and colorectal carcinoma, the $\mathrm{G}$ allele was associated with loss of $p 16^{I N K 4 a}$ and p14 ${ }^{A R F}$ expression, and in glioblastoma, CG genotype was associated with reduced $p 16^{I N K 4 a}$ and $p 14^{A R F}$ gene dosage $(13,14,17)$. The observation that ANRIL levels were higher and negatively correlated with $p 16^{I N K 4 a}$ in patients with the CG genotype, suggests $A N R I L$ may be upregulated and acting to repress $p 16^{I N K 4 a}$ expression. There is evidence to suggest $A N R I L$ affects expression of 9 p21 transcripts by acting as a scaffold to guide chromatinremodeling proteins toward 9p21 (19, 21, 35-37). ANRIL may promote the formation of heterochromatin facilitating reduced expression of $p 16^{I N K 4 a}$ expression. A specific example is the binding of ANRIL to polycomb repressive complexes 1 and 2 (PRC1 and PRC2) that is thought to direct epigenetic regulation and reduced $p 16^{I N K 4 a}$ and $p 15^{I N K 4 b}(19,35)$.

Other data suggest increased ANRIL would be associated with increased rather than decreased expression at 9p21 in breast cancer. Using TCGA expression data for invasive breast cancer, $A N R I L$ and CDKN2A ( $p 14^{A R F}$ and $p 16^{I N K 4 a}$ combined) were positively correlated (Pearson correlation 0.588 , Figure 4A) (38, 39), with a marginal positive correlation between ANRIL and $p 15^{I N K 4 b}$ (Pearson Correlation 0.39, Figure 4B). An analysis of 12 breast tumors by Pasmant et al. (18) found increased ANRIL correlated with increased $p 14^{A R F}, p 16^{I N K 4 a}$, and $p 15^{I N K 4 b}$ (18). The available TCGA data are not divided based on the rs11515 genotype. Considering most women will be homozygote for the major rs11515 allele, the inconsistency between the TCGA data with that from the current study raises the possibility that the relationship between $A N R I L$ and $p 16^{I N K 4 a}$ may be influenced by the rs 11515 genotype, with an inverse relationship for those with the CG but not the CC genotype.

Although we argue that the CG genotype is correlated with increased risk toward breast cancer due to increased nodal involvement, increased ANRIL, and reduced $p 16^{I N K 4 a}$ expression, it could be argued that the CC genotype is the risk genotype. Patients with the CC genotype were younger. In another study, increased rather than decreased expression of $p 16^{I N K 4 a}$ was associated with a higher breast tumor grade and increased proliferative capacity
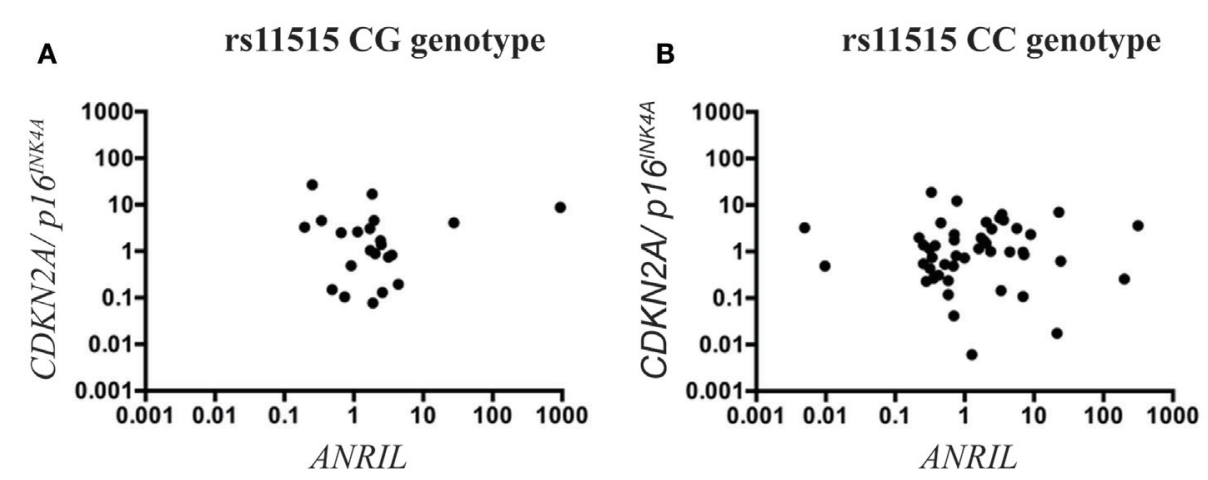

FIGURE 3 | Scatterplots illustrating the interaction between rs11515 genotypes and ANRIL on CDKN2A/p16 ${ }^{\text {INK4a }}$ gene expression in heart tissue. The CG genotype (A) and the CC (B) genotype in heart tissue showed was no correlation between ANRIL and CDKN2ANp16 ${ }^{\text {INK } 4 a}$ expression levels. 

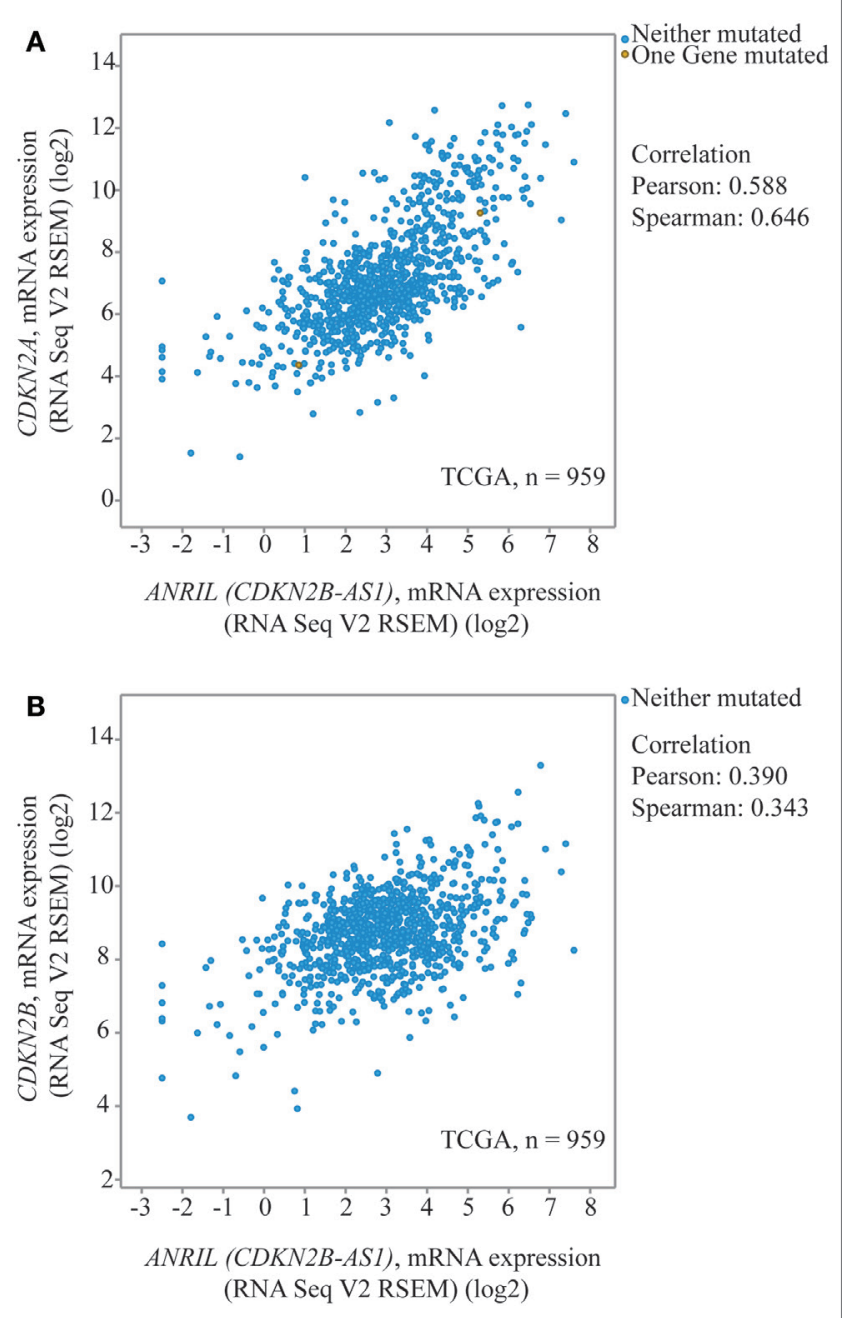

FIGURE 4 | Dot-plots from TCGA data for invasive breast cancer to illustrate correlations between 9p21 transcripts. ANRIL (CDKN2B-AS1)

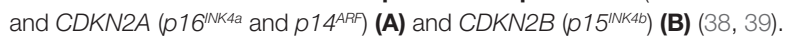

(40). It could be that the CG genotype protects against tumors initially, but with age tumor surveillance may be compromised leading to a more aggressive tumor. The current study did not investigate ANRIL expression in normal associated breast tissue, so we did not determine whether it is the CG or CC genotype that is aberrant for ANRIL expression in breast tumors. Those with the GG genotype were young and this supports the G rs11515 allele being the risk allele for breast cancer. However, few had the GG genotype and breast tissue from GG homozygotes was not available to determine if $A N R I L$ expression is greatest in these women.

The association between the CG genotype and ANRIL did not occur in heart tissue, suggesting the effect of rs11515 alleles is tissue or disease specific. Multiple isoforms of ANRIL exist including both linear and circular forms with tissue-specific expression patterns identified $(41,42)$. ANRIL isoforms with an ALU motif were found to be more effective in recruiting chromatin-remodeling proteins (21). The specific ANRIL isoforms increased in breast tumors were not identified so the tissue-specific differences between breast cancer and myocardium could be attributed to different ANRIL isoforms being present. The rs11515 SNP is predicted to affect the binding site of microRNA-601 (43), so the effect of rs11515 genotypes may be dependent of the expression of other transcripts.

Other 9p21 polymorphisms have been correlated with cancer including breast cancer (rs1011970), glioma (rs1063192, rs2157719, rs1412829, and rs4977756), basal cell carcinoma (rs2151280), nasopharyngeal carcinoma (rs1412829), and breast cancer (rs1011970 and rs3088440) [reviewed in Ref. $(34,44)$ ]. Consequently, another polymorphism in linkage with rs11515 could be the causal allele for the increased ANRIL expression. The rs3088440 polymorphism is located $40 \mathrm{bp}$ downstream of rs11515. In a large cohort of over 3000 women with breast cancer, the rs3088440 minor allele was associated with breast cancer (34), and in pancreatic cancer associated with a reduced time to tumor progression and a poorer response to therapy (45). The rs3088440 genotypes were not significantly increased in the breast cancer cohort in the current study; however, a limitation of the current study was a smaller cohort was used (34). The majority of individuals' heterozygote for the rs 11515 allele were homozygote for the rs3088440 major allele; therefore, it is possible that a haplotype contributes to the associations found in this study instead of the rs11515 genotype alone.

\section{CONCLUSION}

To our knowledge, this is the first report of an association between the rs11515 minor allele with breast cancer and a negative correlation between ANRIL and $p 16^{I N K 4 a}$ levels with the CG genotype. Reduced expression of $p 16^{I N K 4 a}$ may be one mechanism by which the rs 11515 CG genotype increases cancer risk.

\section{AUTHOR CONTRIBUTIONS}

JR - designed and supervised experimental studies, and edited the manuscript; AP - performed PCR, data analysis and interpretation, wrote, and edited the manuscript; AA - performed PCR, analyzed data, and edited the manuscript; HM, MC, CM, WS, WHWT - designed research, interpreted data, and edited the manuscript. CF - performed the statistical analyses, interpreted data, and edited the manuscript; IAR - interpreted TCGA data, designed research, and edited the manuscript; NA - conceived the study, interpreted data, and edited the manuscript. TS - conceived the study, performed PCR, designed research, and wrote and edited the manuscript.

\section{ACKNOWLEDGMENTS}

Ms. Janine Neill and Ms. Amanda Fisher for technical assistance on this project. The Cancer Society Tissue Bank Christchurch, New Zealand.

\section{FUNDING}

Funding for this study was provided by the New Zealand Breast Cancer Foundation. 


\section{REFERENCES}

1. Helgadottir A, Thorleifsson G, Manolescu A, Gretarsdottir S, Blondal T, Jonasdottir A, et al. A common variant on chromosome 9p21 affects the risk of myocardial infarction. Science (2007) 316(5830):1491-3. doi:10.1126/ science. 1142842

2. McPherson R, Pertsemlidis A, Kavaslar N, Stewart A, Roberts R, Cox DR, et al. A common allele on chromosome 9 associated with coronary heart disease. Science (2007) 316(5830):1488-91. doi:10.1126/science.1142447

3. Samani NJ, Erdmann J, Hall AS, Hengstenberg C, Mangino M, Mayer B, et al. Genomewide association analysis of coronary artery disease. $N$ Engl J Med (2007) 357(5):443-53. doi:10.1056/NEJMoa072366

4. Shete S, Hosking FJ, Robertson LB, Dobbins SE, Sanson M, Malmer B, et al. Genome-wide association study identifies five susceptibility loci for glioma. Nat Genet (2009) 41(8):899-904. doi:10.1038/ng.407

5. Bishop DT, Demenais F, Iles MM, Harland M, Taylor JC, Corda E, et al. Genome-wide association study identifies three loci associated with melanoma risk. Nat Genet (2009) 41(8):920-5. doi:10.1038/ng.411

6. Gu F, Pfeiffer RM, Bhattacharjee S, Han SS, Taylor PR, Berndt S, et al. Common genetic variants in the 9p21 region and their associations with multiple tumours. Br J Cancer (2013) 108(6):1378-86. doi:10.1038/bjc.2013.7

7. Li WQ, Pfeiffer RM, Hyland PL, Shi J, Gu F, Wang Z, et al. Genetic polymorphisms in the 9p21 region associated with risk of multiple cancers. Carcinogenesis (2014) 35(12):2698-705. doi:10.1093/carcin/bgu203

8. Ozenne P, Eymin B, Brambilla E, Gazzeri S. The ARF tumor suppressor: structure, functions and status in cancer. Int J cancer (2010) 127(10):2239-47. doi:10.1002/ijc.25511

9. LaPak KM, Burd CE. The molecular balancing act of p16(INK4a) in cancer and aging. Mol Cancer Res (2014) 12(2):167-83. doi:10.1158/1541-7786. MCR-13-0350

10. Aitken J, Welch J, Duffy D, Milligan A, Green A, Martin N, et al. CDKN2A variants in a population-based sample of Queensland families with melanoma. J Natl Cancer Inst (1999) 91(5):446-52. doi:10.1093/jnci/91.5.446

11. Fargnoli MC, Chimenti S, Keller G, Soyer HP, Dal Pozzo V, Hofler H, et al. CDKN2a/p16INK4a mutations and lack of p19ARF involvement in familial melanoma kindreds. J Invest Dermatol (1998) 111(6):1202-6. doi:10.1046/j.1523-1747.1998.00412.x

12. Kreimer-Erlacher H, Seidl H, Back B, Cerroni L, Kerl H, Wolf P. High frequency of ultraviolet mutations at the INK4a-ARF locus in squamous cell carcinomas from psoralen-plus-ultraviolet-A-treated psoriasis patients. $J$ Invest Dermatol (2003) 120(4):676-82. doi:10.1046/j.1523-1747.2003.12085.x

13. Sauroja I, Smeds J, Vlaykova T, Kumar R, Talve L, Hahka-Kemppinen $\mathrm{M}$, et al. Analysis of $\mathrm{G}(1) / \mathrm{S}$ checkpoint regulators in metastatic melanoma. Genes Chromosomes Cancer (2000) 28(4):404-14. doi:10.1002/1098-2264(200008)28:4<404::AID-GCC6>3.0.CO;2-P

14. McCloud JM, Sivakumar R, Greenhough A, Elder J, Jones PW, Deakin M, et al. p16INK4a polymorphism: associations with tumour progression in patients with sporadic colorectal cancer. Int J Oncol (2004) 25(5):1447-52. doi:10.3892/ijo.25.5.1447

15. Sakano S, Berggren P, Kumar R, Steineck G, Adolfsson J, Onelov E, et al. Clinical course of bladder neoplasms and single nucleotide polymorphisms in the CDKN2A gene. Int J Cancer (2003) 104(1):98-103. doi:10.1002/ ijc.10919

16. Vargas-Torres SL, Portari EA, Klumb EM, Guillobel HC, de Camargo MJ, Russomano FB, et al. Association of CDKN2A polymorphisms with the severity of cervical neoplasia in a Brazilian population. Biomarkers (2014) 19(2):121-7. doi:10.3109/1354750X.2014.881419

17. Royds JA, Al Nadaf S, Wiles AK, Chen YJ, Ahn A, Shaw A, et al. The CDKN2A G500 allele is more frequent in GBM patients with no defined telomere maintenance mechanism tumors and is associated with poorer survival. PLoS One (2011) 6(10):e26737. doi:10.1371/journal.pone.0026737

18. Pasmant E, Laurendeau I, Heron D, Vidaud M, Vidaud D, Bieche I. Characterization of a germ-line deletion, including the entire INK4/ARF locus, in a melanoma-neural system tumor family: identification of ANRIL, an antisense noncoding RNA whose expression coclusters with ARF. Cancer Res (2007) 67(8):3963-9. doi:10.1158/0008-5472.CAN-06-2004

19. Yap KL, Li S, Munoz-Cabello AM, Raguz S, Zeng L, Mujtaba S, et al. Molecular interplay of the noncoding RNA ANRIL and methylated histone H3 lysine
27 by polycomb CBX7 in transcriptional silencing of INK4a. Mol Cell (2010) 38(5):662-74. doi:10.1016/j.molcel.2010.03.021

20. Congrains A, Kamide K, Oguro R, Yasuda O, Miyata K, Yamamoto E, et al. Genetic variants at the 9p21 locus contribute to atherosclerosis through modulation of ANRIL and CDKN2A/B. Atherosclerosis (2012) 220(2):449-55. doi:10.1016/j.atherosclerosis.2011.11.017

21. Holdt LM, Hoffmann S, Sass K, Langenberger D, Scholz M, Krohn K, et al. Alu elements in ANRIL non-coding RNA at chromosome 9p21 modulate atherogenic cell functions through trans-regulation of gene networks. PLoS Genet (2013) 9(7):e1003588. doi:10.1371/journal.pgen.1003588

22. Schaefer AS, Richter GM, Groessner-Schreiber B, Noack B, Nothnagel M, El Mokhtari NE, et al. Identification of a shared genetic susceptibility locus for coronary heart disease and periodontitis. PLoS Genet (2009) 5(2):e1000378. doi:10.1371/journal.pgen.1000378

23. Rajaraman P, Melin BS, Wang Z, McKean-Cowdin R, Michaud DS, Wang SS, et al. Genome-wide association study of glioma and meta-analysis. Hum Genet (2012) 131(12):1877-88. doi:10.1007/s00439-012-1212-0

24. Sherborne AL, Hosking FJ, Prasad RB, Kumar R, Koehler R, Vijayakrishnan J, et al. Variation in CDKN2A at 9p21.3 influences childhood acute lymphoblastic leukemia risk. Nat Genet (2010) 42(6):492-4. doi:10.1038/ng.585

25. Cunnington MS, Santibanez Koref M, Mayosi BM, Burn J, Keavney B. Chromosome 9p21 SNPs associated with multiple disease phenotypes correlate with ANRIL expression. PLoS Genet (2010) 6(4):e1000899. doi:10.1371/ journal.pgen.1000899

26. Iranpour M, Soudyab M, Geranpayeh L, Mirfakhraie R, Azargashb E Movafagh A, et al. Expression analysis of four long noncoding RNAs in breast cancer. Tumour Biol (2015). doi:10.1007/s13277-015-4135-2

27. Pilbrow AP, Folkersen L, Pearson JF, Brown CM, McNoe L, Wang NM, et al. The chromosome 9p21.3 coronary heart disease risk allele is associated with altered gene expression in normal heart and vascular tissues. PLoS One (2012) 7(6):e39574. doi:10.1371/journal.pone.0039574

28. Morrin H, Gunningham S, Currie M, Dachs G, Fox S, Robinson B. The Christchurch tissue bank to support cancer research. N Z Med J (2005) 118(1225):U1735.

29. Newcomb EW, Alonso M, Sung T, Miller DC. Incidence of p14ARF gene deletion in high-grade adult and pediatric astrocytomas. Hum Pathol (2000) 31(1):115-9. doi:10.1016/S0046-8177(00)80207-5

30. Andersen CL, Jensen JL, Orntoft TF. Normalization of real-time quantitative reverse transcription-PCR data: a model-based variance estimation approach to identify genes suited for normalization, applied to bladder and colon cancer data sets. Cancer Res (2004) 64(15):5245-50. doi:10.1158/0008-5472.CAN-04-0496

31. Walker LC, Thompson BA, Waddell N, kConFab Investigatiors, Grimmond SM, Spurdle AB. Use of DNA-damaging agents and RNA pooling to assess expression profiles associated with BRCA1 and BRCA2 mutation status in familial breast cancer patients. PLoS Genet (2010) 6(2):e1000850. doi:10.1371/ journal.pgen.1000850

32. Pilbrow AP, Ellmers LJ, Black MA, Moravec CS, Sweet WE, Troughton RW, et al. Genomic selection of reference genes for real-time PCR in human myocardium. BMC Med Genomics (2008) 1:64. doi:10.1186/1755-8794-1-64

33. Shi YY, He L. SHEsis, a powerful software platform for analyses of linkage disequilibrium, haplotype construction, and genetic association at polymorphism loci. Cell Res (2005) 15(2):97-8. doi:10.1038/sj.cr.7290272

34. Turnbull C, Ahmed S, Morrison J, Pernet D, Renwick A, Maranian M, et al. Genome-wide association study identifies five new breast cancer susceptibility loci. Nat Genet (2010) 42(6):504-7. doi:10.1038/ng.586

35. Kotake Y, Nakagawa T, Kitagawa K, Suzuki S, Liu N, Kitagawa M, et al. Long non-coding RNA ANRIL is required for the PRC2 recruitment to and silencing of p15(INK4B) tumor suppressor gene. Oncogene (2011) 30(16):1956-62. doi:10.1038/onc.2010.568

36. Yu W, Gius D, Onyango P, Muldoon-Jacobs K, Karp J, Feinberg AP, et al. Epigenetic silencing of tumour suppressor gene p15 by its antisense RNA. Nature (2008) 451(7175):202-6. doi:10.1038/nature06468

37. Chen D, Zhang Z, Mao C, Zhou Y, Yu L, Yin Y, et al. ANRIL inhibits p15(INK4b) through the TGFbetal signaling pathway in human esophageal squamous cell carcinoma. Cell Immunol (2014) 289(1-2):91-6. doi:10.1016/j. cellimm.2014.01.003

38. Cerami E, Gao J, Dogrusoz U, Gross BE, Sumer SO, Aksoy BA, et al. The cBio cancer genomics portal: an open platform for exploring multidimensional 
cancer genomics data. Cancer Discov (2012) 2(5):401-4. doi:10.1158/21598290.CD-12-0095

39. Gao J, Aksoy BA, Dogrusoz U, Dresdner G, Gross B, Sumer SO, et al. Integrative analysis of complex cancer genomics and clinical profiles using the cBioportal. Sci Signal (2013) 6(269):11. doi:10.1126/scisignal.2004088

40. Milde-Langosch K, Bamberger AM, Rieck G, Kelp B, Loning T. Overexpression of the p16 cell cycle inhibitor in breast cancer is associated with a more malignant phenotype. Breast Cancer Res Treat (2001) 67(1):61-70. doi:10.1 023/A:1010623308275

41. Folkersen L, Kyriakou T, Goel A, Peden J, Malarstig A, Paulsson-Berne G, et al. Relationship between CAD risk genotype in the chromosome 9p21 locus and gene expression. Identification of eight new ANRIL splice variants. PLoS One (2009) 4(11):e7677. doi:10.1371/journal.pone.0007677

42. Burd CE, Jeck WR, Liu Y, Sanoff HK, Wang Z, Sharpless NE. Expression of linear and novel circular forms of an INK4/ARF-associated non-coding RNA correlates with atherosclerosis risk. PLoS Genet (2010) 6(12):e1001233. doi:10.1371/journal.pgen.1001233

43. Landi D, Gemignani F, Barale R, Landi S. A catalog of polymorphisms falling in microRNA-binding regions of cancer genes. DNA Cell Biol (2008) 27(1):35-43. doi:10.1089/dna.2007.0650
44. Pasmant E, Sabbagh A, Vidaud M, Bieche I. ANRIL, a long, noncoding RNA, is an unexpected major hotspot in GWAS. FASEB J (2011) 25(2):444-8. doi:10.1096/f.10-172452

45. Chen J, Li D, Wei C, Sen S, Killary AM, Amos CI, et al. Aurora-A and p16 polymorphisms contribute to an earlier age at diagnosis of pancreatic cancer in Caucasians. Clin Cancer Res (2007) 13(10):3100-4. doi:10.1158/1078-0432. CCR-06-2319

Conflict of Interest Statement: The authors declare that the research was conducted in the absence of any commercial or financial relationships that could be construed as a potential conflict of interest.

Copyright $\odot 2016$ Royds, Pilbrow, Ahn, Morrin, Frampton, Russell, Moravec, Sweet, Tang, Currie, Hung and Slatter. This is an open-access article distributed under the terms of the Creative Commons Attribution License (CC BY). The use, distribution or reproduction in other forums is permitted, provided the original author(s) or licensor are credited and that the original publication in this journal is cited, in accordance with accepted academic practice. No use, distribution or reproduction is permitted which does not comply with these terms. 